\title{
THE PROJECT AND PROJECT METHOD IN GENERAL SCIENCE.1
}

\author{
By GarField A. Bowden, \\ University School, Cincinnati, Ohio. \\ The Master of Project Method.
}

In Dole, France on Friday, December 27, 1822, at 2:00 in the morning, Louis Pasteur was born. The event was unheralded and quite unknown outside of the usual circle of family relatives and acquaintances of the neighborhood. At Villeneuve l'Etang on Saturday, September 28, 1895, at 4:40 in the afternoon occurred the death of Louis Pasteur. The death of the "First Man of France" was lamented not only by the great civic and scientific circles but by the lonely shepherd on the steeps bordering the foothills of the Urals and the rough caravan trader of the Orient, in short, from the far corners of the earth came expressions of regret mingled with gratitude in memory of a common benefactor. Indeed his name had already become a noun or a verb or both in nearly every written language. This man had become world famous, world honored and world beloved, solely by his own achievements. No army or navy, no inherited kingship or emperorship, no political, industrial or religious revolution brought about his rise to the pinnacle of world recognition-simply the inheritance of an intellect which he willed and purposed to the service of humanity.

Rene Vallery-Radot, his son-in-law, records that "he was full of projects, and what he called the 'spirit of invention' daily suggested some new undertaking." The nature of these "undertakings" are suggested in the following statements:

1. To establish the truth or falsity of the so-called "spontaneous generation."

2. To discover causes and effect remedies for the "diseases" in vinegar and wines.

3. To discover causes and effect remedies for "charbon" or splenic fever.

4. To set forth to the world the "germ theory of disease."

5. To establish by public experiment at Pouilly le Fort the success of vaccination as a preventive for splenic fever.

6. To make a study of the hydrophobia problem and to work out a preventive treatment of rabies.

The above projects in the order stated, associated with in-

tRead before the General Srience Section of the C. A. S. and M. T., Soldan High School, St. Lonis, Missouri, and read before the Parent-Teachers Association, University School, Cincinnati, Obio, Dec. 1. 1921. 
numerable others, presented themselves to the mind of louis Pasteur in the short space of twenty years. Pasteur's attack and successful conclusion of the above "undertakings" so related to the surety and happiness of life is well known and needs no recounting here, but a resume of Pasteur's method of conducting a research is worthy of serious attention, for, by so doing, we provide an opportunity for examining the "workings of a project method" in the hands of a master workman.

The Status of the Hydrophobia Problem Previous to Pasteur's Attack.

The most interesting of Pasteur's projects in preventive and curative medicine is concerned with his investigation of the dread disease of hydrophobia in man and rabies in animals. Prior to Pasteur's successful combat, hydrophobia remained one of the most mysterious and most fell disease to which man is subject. Homer has a warrior called Hector a mad dog. Aristotle speaks of the transmissions from one animal to another through bites and says that man is not subject to it. Some three centuries later Celsus records, "The patient is tortured at the same time by thirst and by an invincible repulsion towards water." The historical methods of treating this disease were stupid, torturous and criminal. The use of corrosives and various caustics and cauterizing of bites with a red hot iron were advised. As a cure, Pliny the Elder recommended the livers of mad dogs. Galen opposed Pliny's recipe with a compound of cray-fish eyes. During the reign of Louis XIV sea bathing, heretofore unknown in France, became a fashionable cure for hydrophobia. These and many other quack remedies were the vogue. The long period of incubation required for the development of this disease only added misery and desolation to the unfortunate victims of the bites of rabid animals. They were outcasts to whom quarter and comfort were seldom, if ever, given. In many sections it became the custom to shoot, poison, strangle, suffocate or drown persons merely suspected of hydrophobia. As late as 1819 the Paris newspapers related the death by strangling and smothering between mattresses an unfortunate person suspected of hydrophobia. In 1831 Pasteur, a child of nine years, witnessed the terror spread by a rabid wolf and had seen the wounds of a victim cauterized with a red hot iron at the smithy. The cauterized victim lived, but several others after horrible 
sufferings succumbed to the dread disease. Amidst the various researches undertaken by Pasteur one study was placed by him above every other, the one mystery of his mind-the mystery of hydrophobia. Yet Pasteur was near his sixtieth year of life before he found himself prepared and ready to attack this most fateful of all diseases.

\section{Pasteur's Attack and Solution of the Hrdrophobia Problem.}

In the foregoing we set forth the conditions in which Pasteur found a research problem. Now let us examine and observe the methods of attack, of procedure; of organization and of definition that Pasteur employed in order to bring about the solution of the problem in hand. Let us observe the advancement made in each step taken, and how the results obtained at each and every step pointed out to his keen and plastic mind the next required step and thus to the successful termination of the undertaking. The major steps in the solution of the hydrophobia problem were as follows:

1. To begin, Pasteur made a study of rabid dogs. Countless laboratory experiments were carried on while making this study of rabid dogs. This first step led him to conclude that the virus had its seat in the nerve centers.

2. A closer study directed at the nerve centers led him to inject a portion of the matter of the spinal column of a rabid dog into the body of a healthy dog. Results of such injections invariably produced the symptoms of rabies.

3. The next step was to endeavor so to modify and weaken the virus as to enable it to be used as a preventive or as an antitoxin. This proved to be a vexing undertaking, but after long and serious labor he obtained the much desired result, namely an inoculated dog to be immune when bitten by a rabid animal.

4. But this was not enough. Would the inoculation of the attenuated virus have a remedial effect on an animal already bitten? A number of dogs were inoculated, the same number were untreated, and both sets bitten by rabid animals. All treated dogs lived; all the untreated died from rabies.

5. It was, however, one thing to experiment on dogs, and quite another to do so on human beings. Nevertheless Pasteur was bold enough to try. The trial was successful and by so doing he earned the gratitude of the human race. 
This simple portrayal of Pasteur's activities may be misleading to some of us. We may think that the passing from step to step was a very simple matter, and that Pasteur saw from the beginning a well defined method of procedure that was certain of the desired results. Such was not the case. Each step taken was beset with difficulties and obstacles that required a sacrifice of mind and body that few men care to make. Literally hundreds of experimental trials and retrials were made at every step in order to obtain an insight that would point out the next successful step. This recital of Pasteur's attack, his conquest, and triumphant victory over this disease lays before us the "workings of the project method" in the hands of a master.

\section{Characteristics of the Project Method.}

Time and space prevent the consideration of the other masters in other fields of activity. Suffice to say, however, that Galileo, Lavoisier, Davy, Faraday, Kelvin, Ramsay and others exemplified throughout their lives and undertakings the principles of the project method. The method employed by the masters is simply a natural method of procedure that may be analyzed into the following characteristic stages that are more or less interrelated than well defined:

1. A doubtful or perplexed state of mind regarding a given question, problem or situation.

2. A conviction that the problem or situation is worthy and reasonably possible of solution.

3. A quest in search of information and experience pertinent to the problem or question in hand.

4. An establishment of theories, guesses, or hypotheses that serves as a means to the end.

5. An arrangement or a formulation of facts and evidence that follows through to successful conclusion-a conclusion that dispells the perplexity of mind-a conclusion that may or may not be final.

The identities of the project method as set forth above are not only characteristic of the activities of Edison or Michelson or Madame Curie, but of children before entering school and of children and teachers out of school. In short the project method is a natural procedure undertaken by a self willed individual or individuals in quest of pertinent information that will dispell to a more or less degree a perplexity of mind. 


\section{Project Method Depends upon the Purpose of the Course.}

Now is it possible to adapt the method of the scientist to children pursuing a course in general science? The answer to this question is determined solely by the purpose we assign to such a course. If we as teachers use the course as an opportunity to impart our knowledge of the subject matter or to merely interpret some one else's knowledge of the subject matter as set down in a text, we shall have succeeded as haranguers and interpreters to an audience who listens, well today and forgets much tomorrow. On the other hand if the purpose of the course is to provide an occasion means by which the children are stimulated to seek information in the achievement of ends sought, then the method of the scientist-essentially the project method-is adaptable.

\section{The Necessity of a Scientific Attitude.}

Teachers who are in the habit of assigning so much codified subject matter accompanied by a set of formal experiments, lecture or laboratory, fail to develop the scientific attitude in their pupils. A course in any science that makes no provision for initative on the part of the pupil, no provision for the selection of facts according to their value, no provision for trial, no provision for creative thinking can ever boast of imparting to the least degree the spirit of scientifie attitude. Without a development of a scientific attitude how can there be growth of power in the judgment and appreciation of values? Without the scientific attitude how can there be any desire for nice discriminations-accurate selection or rigid elimination?

\section{The Project.}

Thus far much has been said about the project method and little about the project. This condition of affairs is deliberate. For the writer contends that if one is familiar with the project method, the concept of what a project is and what a project is not is quite obvious. So long as Pasteur viewed from a distance the hydrophobia problem it remained a problem. But the moment that he challenged the problem, the moment that he began to investigate it in its own field of action, the moment that he began to define it or establish an hypothesis concerning it and to draw conclusions which would verify and thus directed his labors to bring the undertaking to a successful conclusion, that moment the problem became Pasteur's project-Kilpatrick 
would say "the purposeful act" of Pasteur. In the pursuit of this project Pasteur consumed a great deal of time and energy. Indeed at one stage of its development Pasteur found himself physically wrecked and invalided, yet he prevailed and succeeded in driving the undertaking to a suecessful conclusion. This element of success has become indentified as a fundamental of the project. Again Pasteur pursued his project in surroundings that were wholly fitting to the question in hand, that is, the setting was natural. In summary, then, a project is a "purposeful act" pursued in a natural setting to a successful conelusion.

Formal Methods Versus the Project Method.

From the foregoing considerations we readily see that there is nothing new in the project or project method. Indeed, it has been used to a greater or less extent throughout the schools of the land by teachers who sought to inject into their several courses an actuality and a worthiness of enterprise that could not thus be obtained from the old and time-honored methods known as topic, problem and question. The teacher of general science may assign topics on ventilation from the text in hand, from references, or, in fact, may develop the principles from drawings on the board or chart and require the pupils to acquire a mastery of details and principles thus assigned and presented. This method of procedure is convenient; and it is, indeed, quite the habit. It is not problematical to say that the majority of the children have had no previous interest in the topic or subject thus assigned, no "set of feelings" of decided worthiness established in behalf of the question in hand. However, the discipline of the school demands preparation, a preparation of an artificial sort.

On the other hand the teacher may do the more natural thing which is that of having the pupils and himself observe and make a study of the ventilation of the room in which they find themselves situated, and from thence to that of the building in which the room is located. This sort of procedure arouses an interest that aids to establish a "set of feelings" for the thing in question. Such a "set of feelings" usually urges the possessor to seek further satisfaction by continuing the investigation of the affair. Such pupils will of their own accord investigate the home heating plant and modifications of the same as found in various other types of buildings. In fact, if the teacher is 
in the habit of approaching the situations and problems of the course by examining the situation or problem as it exists in the child's environment-home and community-the ehild soon forms the habit of "carrying on." A multitude of minor and personal problems will occur to him. Some of these problems will be found worthy of acceptance, investigation, and definition, and indeed, they will have become "purposeful activities." As such a course proceeds, the spirit of inquiry develops as a logical sequence.

The results obtained from this latter method of procedure are denied and contested by those teachers who have always made use of the more formal and time-worn method of demanding a knowledge of fact and principle in priority of a study of the situation or problem in its natural setting. The course that demands priority of fact and prineiple seldom, if ever, develops a scientific attitude. Indeed, why should it? The child who finds himself in such a course has no need or use of a spirit of inquiry, for fact and principle are learned from the first, and hence the fact or principle becomes for the child a sort of a fairy wand which, when applied with proper rite and due ceremony, dispells or transforms the problematic situation that arises later. Such a child has had his intellectual appetite satisfied with no accompanying mental digestion.

\section{A Background that Fosters a Spirit of Inouiry Is NECESSARY.}

Teachers who have never used the project method in the sciences should not attempt the method on a twenty-four-hour decision. The project method requires preparation, tact and patienee. At first the results are discouraging. The pupils have been and are pursuing courses in other branches that are largely formal, and the pupils are so accustomed, and hence their eonduct in which a project method is used for the first time is not one from habit. Right habits and attitudes will develop in direct proportion to the development of a spirit of honest inquiry into the how and the why of things. At first the background of the course should give rise to simplc problems in which the pupil sees a possibility of solution and a worthiness of pursuit. The following exemplifies the point in question and is a verbatim copy of a reported activity of one of the girls of the eighth grade general science course in the UniversitySchool at Cincinnati. The problem arose out of a background that had to do with clothing materials. 
M. $\mathrm{F}$

Grade $1 . .1 . .$.

University-Sohool

General Science

Heat Conducting Properties by Woolen and Cotton Materials.

The question was put before the class, "Which is the better material for winter wear wool or eotton?" Deciding to find out, I took two similar tin cans, a piece of serge and piece of gingham, two corks and two thermometers.

I took the cans, put a hole in the top and also a hole through the corks by means of a file. I then put on the lid of each can and put two layers of serge around one ean and two layers of gingham around the other, also over the tops and bottoms, leaving a space in the top of each directly above the holes so that I could put in the cork and the thermometer. Then I took a funnel placed it in the hole and poured the same amount of water in each.

I then pushed a thermometer through each cork and put a cork in each hole. The readings were:

$\begin{array}{lrll} & & \\ \text { October 22, 1921. } & \text { Time } & \text { Cotton } & \text { Wool } \\ & 3: 47 & 83^{\circ} \mathrm{C} & 82.5^{\circ} \mathrm{C} \\ & 4: 32 & 61 & 63 \\ & 5: 10 & 52.5 & 57 \\ & 6: 07 & 44 & 50.5 \\ & 7: 05 & 37 & 45 \\ & 8: 17 & 31.5 & 41 \\ & 9: 26 & 27 & 39.5\end{array}$

In 5 hours and 39 minutes, can with the cotton material dropped $56^{\circ} \mathrm{C}$. and the can with the wool dropped $43^{\circ} \mathrm{C}$. Altogether the ean with cotton dropped $13^{\circ} \mathrm{C}$ more than the ean with wool.

Conclusion:

Cotton is a much better conduetor than wool. This also explains the reason why we wear elothes of cotton materials in summer rather than woolen ones. It also answers a question I saw the other day about firemen wearing woolen shirts in summer time. The fires that they tend are hotter than their bodies. The woolen shirts are poor conductors and keep the heat away from their bodies.

While the above exposition of affairs is somewhat awkward, it sets forth, an order of events that is unmistakable and worthy of merit. A mastery of simple perplexities lays a basis for the attack and mastery of the more complex. If a pupil fails to master a task set by another the failure is often excusable, but when a pupil undertakes a self-set task and fails, his self-confidence is weakened-especially so, if the background from which the problem sprung held forth glittering possibilities that were from the first untenable. A course in projects does not mean the complete elimination of the topic, question and problem methods of instruction. These latter methods are enriched and made more possible when preceded or accompanied by related projects. In setting forth a course in general science by means of projects the teacher is the skilled tactician, the silent general who guides and directs the uninitiated from the mastery of simple mysteries of life and nature to those more complex. Serfs and slaves had their tasks assigned, and moreover task masters set over them to drive them to the conclusion of the task-not their task. When "knighthood was in flower" this condition of affairs was acceptable. 